\title{
Effect of Farm Yard Manure and Phosphorus Levels on Yield and Yield Components of Wheat
}

\author{
*Muhammad Aatif, Hamayoon Khan, Muhammad Mehran Anjum, Nawab Ali and Muhammad Hamid \\ Department of Agronomy, University of Agriculture, Pakistan
}

Submission: May 01, 2017; Published: June 14, 2017

*Corresponding author: Muhammad Aatif, Faculty of Crop Production Sciences, University of Agriculture, Peshawar, Pakistan, Email: maatif@aup.edu.pk

\begin{abstract}
To study the effect of phosphorus and FYM on yield and yield components of wheat an experiment was conducted at Agronomy Research Farm, The University of Agriculture, Peshawar, during winter 2014-15. The experiment consisted of randomize complete block design having split plot arrangement with four replications. Animal manure (FYM) was applied to main plots while phosphorus (P) was applied in sub plots. Sub plot size of $3 \times 2 \mathrm{~m}$ was used. FYM was applied 15 days before sowing. Phosphorus was applied at the rate of $0,60,90$ and $120 \mathrm{~kg} \mathrm{ha}^{-1}$. During the course of the study, it was found that P and FYM significantly affected spike length, grain per spike, biological yield, thousand grain weight, grain yield and harvest index of wheat. Higher spike length $(9 \mathrm{~cm})$ was recorded in plots treated with $120 \mathrm{~kg} \mathrm{P}^{\mathrm{P}} \mathrm{a}^{-1}$. Moreover, $\mathrm{P}$ at the rate of $60 \mathrm{~kg} \mathrm{ha}^{-1}$ produced more grains spike ${ }^{-1}$ and grain yield. Similarly FYM at the rate of 9 tons ha ${ }^{-1}$ resulted in highest spike length, grains spike $^{-1}$ and grain yield. Control plots resulted in lower number of grains spike ${ }^{-1}$, spike length and grain yield. It was concluded from the results that application of $\mathrm{P}$ at the rate of $120 \mathrm{~kg} \mathrm{ha}^{-1}$ and FYM at the rate of 9 tons ha-1 improved yield and yield components of wheat.
\end{abstract}

Keywords: FYM; Phosphorous; Yield and yield Components; Wheat

\section{Introduction}

Wheat (Triticum astivum $L$ ) belongs to the family Poaceae. Wheat is an annual, self-pollinated long day winter cereal. It is grown on 8303 thousand ha-1 through whole outcome of $26.21 \mathrm{~m}$ ton in Pakistan with average yield 2844 kilogram per hectare MINFAL [1]. It is the major stable food for the inhabitant of Pakistan Malik [2]. The optimum yield at farmers is greatly lower than required probable level of yield Manin et al. [3]. In irrigated area of KPK wheat is grown on 0.313 million hectares with an average of $1860 \mathrm{~kg} / \mathrm{ha}$. Among Rabi cereal crops wheat is a dominant crop of district Mardan, Mansehra, Kohistan, Peshawar and Swat. Increase in the population pressure demand for wheat production increase in Pakistan by growing the yield production per unit area will complete the requirement of wheat.

As great progress has been achieved in wheat yield per unit area, but it is still below the average yield as compared to other wheat producing countries of the world. There are many constrains to higher yield e.g. environmental stresses which are hampering the attainment of potential maximum grain yield. The application of energy intensive agriculture inputs such as fertilizers, herbicides and pesticides are becoming prohibitively expensive and thus greater production will have to be achieved mainly by further improvement in productivity of wheat. In order to our come this short fall in wheat productivity, the latest production technologies that emphasize on the use of adequate inputs and other techniques like proper agronomic practices are to be followed. Wheat, being an exhaustive crop not only depletes the soil fertility but also degrades its physical properties Singh and Singh (2001). The soil of Khyber Pakhtunkhwa is very low in organic matter, nitrogen, phosphorous and zinc Idris et al. [4]. Chemical fertilizers are used at high level by the farmer to get maximum output per unit area Ahmad [5].

Manure application plays a very important role in improving the fertility of the soil. Manures are bulky organic material taken from plant and animals wastes and extracted. To use of decomposed organic residues David et al. [6] combination of synthetic and organic P fertilizer are believed to improve agriculture productivity in sustainable ways Torbert et al. (2001) the amendment of organic manure enhances soil organic carbon more than the application of the same amount nutrient as inorganic fertilizer Gregorich et al. [7].

Soil type, types of crops, water requirement, P fertilizer, management practices and time of application and climatic condition of an area are important factors to be considered when attempting to formulate sound $\mathrm{P}$ fertilizer source and 
application for maximum crops yield response Amanullah et al. (2010) Amending the soil with animal manures to increase soil fertility has been a common practice throughout the history Griffin et al. [8]. The combined application of inorganic and organic amendments like FYM green manures and residue straw improve their effectiveness. Yaduvanshi and Sharma (2008) found that application of FYM with chemical amendment increase the wheat yield and N, P, K, uptake in grain yield.

Biological Processes are vitally important for enhancing phosphorus (P) availability to crops, especially those that are receiving organic amendments as their major nutrient source Nziguheba and Bu nemann (2005). The major role of mineral fertilizers is to improve crop yields but the main constraint in achieving proven crop potential is low use of fertilizers particularly that of $\mathrm{P}$ and $\mathrm{K}$ as compared to $\mathrm{N}$ Anon (2002) as $\mathrm{P}$ is an expensive nutrient compared to $\mathrm{N}$, and wheat commonly suffers from $\mathrm{P}$ deficiency while grown on alkaline calcareous soils, it is therefore imperative to manage it properly to achieve maximum benefits. Overall $90 \%$ of Pakistan soils are low in available $\mathrm{P}$ and suffer from moderate to severe $\mathrm{P}$ deficiency Ahmad et al. [9] and Nisar et al. (1992). Plants require adequate $\mathrm{P}$ from the very early stages of growth for optimum production. $\mathrm{P}$ decrease lodging by providing strength to the straw in cereals. It increases crop resistance to certain diseases. It plays an inevitable role in plant growth promotion, cell division and nucleus formation. It is also responsible for ribonucleic acid (RNA) and (DNA) formation which are responsible for heredity transmission; it stimulates early growth and root formation. Grain yield and $\mathrm{P}$ accumulation by wheat are highest for higher $\mathrm{P}$ rates Singh et al. (2000).

Unlike nitrogen, phosphorus is relatively immobile in the soil. Consequently, phosphorus placement is expected to cause larger effects on phosphorus availability and crop yield. Research has shown that applying phosphorus with the seed can increase both spring wheat and winter wheat yield compared to deep banding or broadcasting, even in the soils having high amount of phosphorus Jackson et al. (1991) and Jackson et al. (1997). The effective placement of fertilizers can maximize both yields a nutrient use efficiency thereby increasing net profit for the producer. With advances in technology placement option have increased in the past few decades. In addition, a large amount of research has been conducted in the past 25 years on the effects of various placement methods on crop yield, quality, emergence fertilizer use efficiency weeds, and water quality.

Keeping in view the above task, the present study was designed to investigate the effect of FYM and phosphorus on growth, yield and yield component of wheat.

\section{Materials and Methods}

To study the effect of phosphorus and FYM on yield and yield components of wheat. The experiment was carried out at Agronomy Research Farm, The University of Agriculture,
Peshawar, during Rabi season 2014-15. The experiment was conducted in randomize complete block design having split plot with four replications. Farm Yard Manure will be allocated to main plot while Phosphorus source will be allocated to sub plots. Different rates of FYM will be allocated to the main plots while phosphorus levels will be allocated to sub plots. Plots size will be $3 \mathrm{~m} \times 2.1 \mathrm{~m}$. Seed rate for wheat variety Atta Habib will be used as $120 \mathrm{~kg} \mathrm{ha}^{-1}$ on flat beds with $30 \mathrm{~cm}$ row to row distance. Farm Yard Manure rates (FYM1 $=0 \mathrm{t} \mathrm{ha}^{-1}, \mathrm{FYM} 2=3 \mathrm{t} \mathrm{ha}^{-1}$, FYM3 $=6 \mathrm{tha}^{-1}$, FYM4 $=9 \mathrm{t} \mathrm{ha}^{-1}$ ) will be applied 15 days before sowing. Phosphorus will be applied as 0, 60, 90 and $120 \mathrm{~kg} \mathrm{ha}^{-1}$. All the other agronomic practices will be applied uniformly to all the treatments. The experiment will be consists of the following factors along with their respective levels.

\section{Results}

\section{Spike Length $(\mathrm{cm})$}

Table 1: Spike length of wheat as affected by FYM and Phosphorous.

\begin{tabular}{|c|c|c|c|c|c|}
\hline & \multicolumn{5}{|c|}{ Farm yard manure(ton ha-1) } \\
\hline $\mathbf{P}\left(\mathbf{k g ~ h a}^{-1}\right)$ & $\mathbf{0}$ & $\mathbf{3}$ & $\mathbf{6}$ & $\mathbf{9}$ & Means \\
\hline 0 & 8.2 & 8.0 & 8.3 & 8.8 & $8.4 \mathrm{~b}$ \\
\hline 60 & 8.5 & 8.5 & 8.6 & 8.6 & $8.6 \mathrm{~b}$ \\
\hline 90 & 8.6 & 9.0 & 9.1 & 9.0 & $8.9 \mathrm{a}$ \\
\hline 120 & 8.5 & 9.2 & 9.2 & 9.3 & $9.0 \mathrm{a}$ \\
\hline Means & $8.4 \mathrm{~b}$ & $8.7 \mathrm{ab}$ & $8.8 \mathrm{a}$ & $8.9 \mathrm{a}$ & \\
\hline
\end{tabular}

LSD value for FYM at 0.05 probability level $=0.03$.

LSD value for Phosphorus at 0.05 probability level $=0.04$.

Data regarding spike length is reported in (Table 1). Statistical analysis of the data revealed that maximum spike length $(9 \mathrm{~cm})$ was recorded in plots treated with $120 \mathrm{~kg} \mathrm{P} \mathrm{ha}^{-1}$. Lowest spike length value of $(8.4 \mathrm{~cm})$ was observed in plot that received no Phosphorus. Similarly FYM at the rate of 9 tons ha- ${ }^{-1}$ gives highest spike length value of $(8.9 \mathrm{~cm})$. The lowest value of $(8.2 \mathrm{~cm})$ spike length was observed in control plots that received no $\mathrm{P}$ and FYM. Increase in both FYM and P shows increase in spike length.

\section{Grain per spike}

Table 2: Grain spike-1 of wheat as affected by FYM and Phosphorus.

\begin{tabular}{|c|c|c|c|c|c|}
\hline P (kg ha-1 $)$ & \multicolumn{5}{|c|}{ Farm yard Manure(ton ha-1 ${ }^{-1}$} \\
\hline & $\mathbf{0}$ & $\mathbf{3}$ & $\mathbf{6}$ & $\mathbf{9}$ & Means \\
\hline 0 & 56.8 & 88.2 & 83.3 & 84.5 & $78.2 \mathrm{~b}$ \\
\hline 60 & 82.5 & 79.9 & 88.8 & 87.6 & $81.7 \mathrm{a}$ \\
\hline 90 & 81.5 & 55.0 & 86.2 & 89.1 & $77.9 \mathrm{~b}$ \\
\hline 120 & 80.3 & 75.3 & 88.2 & 80.9 & $84.7 \mathrm{a}$ \\
\hline Means & $73.8 \mathrm{~b}$ & $74.6 \mathrm{~b}$ & $86.6 \mathrm{a}$ & $85.5 \mathrm{a}$ & \\
\hline
\end{tabular}

LSD value for FYM at 0.05 probability level $=0.03$.

LSD value for Phosphorus at 0.05 probability level $=0.04$. 
Data regarding grain per spike shown in (Table 2). Statistical analysis of data revealed that effect of FYM, phosphorus significantly affected grain per spike, while interaction between (P x FYM) was also found significant. Mean values showed that the maximum grain per spike (86.7) was found in the plot treated with 9 tons ha-1 FYM, while minimum (74.6) was recorded from plot treated without ton $\mathrm{ha}^{-1}$. However phosphorus at the rate of $120 \mathrm{~kg} \mathrm{ha}^{-1}$ produced maximum grain per spike (84.7) while minimum (77.9) was reported from plot treated with 60 ton $\mathrm{ha}^{-1}$. Similarly in interaction the maximum biological yield (89.1) was recorded from plot receiving 9 tons $\mathrm{ha}^{-1} \mathrm{FYM}$ while minimum (55) was recorded from plot receiving 3 tons ha ${ }^{-1}$ FYM and 90 $\mathrm{kg} \mathrm{ha}^{-1}$.

\section{Biological yield (kg ha-1)}

Table 3: Biological yield $\left(\mathrm{kg} \mathrm{ha}^{-1}\right)$ of wheat as affected by FYM and Phosphorus.

\begin{tabular}{|c|c|c|c|c|c|}
\hline \multirow[t]{2}{*}{$P\left(\mathrm{~kg} \mathrm{ha}^{-1}\right)$} & \multicolumn{5}{|c|}{ Farm yard Manure(tons ha $^{-1}$ ) } \\
\hline & $\mathbf{0}$ & 3 & 6 & 9 & Means \\
\hline 0 & 7835.8 & 8041.3 & 6833.3 & 9674.5 & $8096.2 \mathrm{c}$ \\
\hline 60 & 8998.9 & 9726.0 & 9812.5 & 10159.5 & $9674.2 \mathrm{~b}$ \\
\hline 90 & 9769.8 & 8770.4 & 9291.7 & 10299.7 & $9532.9 \mathrm{~b}$ \\
\hline 120 & 8773.2 & 10791.7 & 12250.0 & 12604.2 & $11104.8 \mathrm{a}$ \\
\hline Means & $8844.4 b$ & $9332.3 \mathrm{~b}$ & $9546.9 \mathrm{ab}$ & $10684.5 \mathrm{a}$ & \\
\hline
\end{tabular}

LSD value for FYM at 0.05 probability level=1061.67.

LSD value for Phosphorus at 0.05 probability level $=821.87$.

Data regarding biological yield is shown in (Table 3). Statistical analysis of data revealed that effect of FYM, phosphorus and interaction between the (P x FYM) significantly affected biological yield. Mean values showed that the maximum biological yield (10684 $\mathrm{kg} \mathrm{ha}^{-1}$ ) was found in the plot treated with 9 tons ha-1 FYM, while minimum (8844.4 $\mathrm{kg} \mathrm{ha}^{-1}$ ) was recorded from plot treated without ton ha-1. However $120 \mathrm{~kg}$ ha-1 phosphorus produced maximum biological yield (11104.8 $\mathrm{kg} \mathrm{ha}^{-1}$ ) while minimum (8096.2 $\left.\mathrm{kg} \mathrm{ha}^{-1}\right)$ was obtain at $0 \mathrm{~kg} \mathrm{ha}^{-1}$ phosphorus. similarly in interaction the maximum biological yield (12604.2 $\mathrm{kg} \mathrm{ha}^{-1}$ ) was recorded from plot receiving 9 tons ha ${ }^{-1}$ FYM and $120 \mathrm{~kg} \mathrm{P}^{-1}$ while minimum $(6833.3 \mathrm{~kg}$ ha$\left.{ }^{1}\right)$ was recorded from plot receiving 6 tons $\mathrm{ha}^{-1} \mathrm{FYM}$ and $0 \mathrm{~kg}$ phosphorus ha-1.

\section{Grain yield (kg ha-1)}

Data regarding biological yield is shown in (Table 4). Statistical analysis of data revealed that effect of FYM, phosphorus significantly affected grain yield. Mean values showed that the maximum grain yield (4691.6 $\mathrm{kg} \mathrm{ha}^{-1}$ ) was found in the plot treated with 9 tons ha ${ }^{-1}$ FYM, while minimum (3306.3 $\mathrm{kg} \mathrm{ha}^{-1}$ ) was recorded from plot treated without FYM ton ha-1. However $120 \mathrm{~kg} \mathrm{P}^{-1}$ produced maximum grain yield (4251.2 $\mathrm{kg} \mathrm{ha}^{-1}$ ) while minimum (3700.5 $\left.\mathrm{kg} \mathrm{ha}^{-1}\right)$ was reported from plot treated with $0 \mathrm{~kg} \mathrm{P} \mathrm{ha-1}$. While interaction between (P x FYM) was found non-significant.
Table 4: Grain yield $\left(\mathrm{kg} \mathrm{ha}^{-1}\right)$ of wheat as affected by FYM and Phosphorus.

\begin{tabular}{|c|c|c|c|c|c|}
\hline P $\left(\right.$ kg ha $\left.^{-1}\right)$ & \multicolumn{5}{|c|}{ Farm yard Manure $\left(\right.$ ton $^{-1} \mathbf{)}$} \\
\hline & $\mathbf{0}$ & $\mathbf{3}$ & $\mathbf{6}$ & $\mathbf{9}$ & Means \\
\hline 0 & 2995.8 & 3701.0 & 3874.8 & 4230.6 & $3700.5 \mathrm{~b}$ \\
\hline 60 & 3021.5 & 3630.5 & 3839.8 & 4711.8 & $3800.9 \mathrm{~b}$ \\
\hline 90 & 3635.8 & 4139.2 & 4122.5 & 4696.3 & $4148.4 \mathrm{a}$ \\
\hline 120 & 3572.3 & 3920.0 & 4384.9 & 5127.8 & $4251.2 \mathrm{a}$ \\
\hline Means & $3306.3 \mathrm{c}$ & $3847.7 \mathrm{bc}$ & $4055.5 \mathrm{~b}$ & $4691.6 \mathrm{a}$ & \\
\hline
\end{tabular}

LSD value for FYM at 0.05 probability level $=475.18$.

LSD value for Phosphorus at 0.05 probability level= 305.33 .

\section{Thousand grain weight (g)}

Table 5: Thousand grain weight (gm) of wheat as affected by FYM and Phosphorus.

\begin{tabular}{|c|c|c|c|c|c|}
\hline $\mathbf{P}\left(\mathbf{k g ~ h a}^{-1}\right)$ & \multicolumn{5}{|c|}{ Farm yard Manure (tons $\mathbf{h a}^{-1}$ ) } \\
\hline & $\mathbf{0}$ & $\mathbf{3}$ & $\mathbf{6}$ & $\mathbf{9}$ & Means \\
\hline 0 & 40.0 & 42.3 & 46.5 & 52.3 & $45.3 \mathrm{~b}$ \\
\hline 60 & 42.8 & 51.3 & 48.0 & 48.5 & $47.6 \mathrm{ab}$ \\
\hline 90 & 44.3 & 51.0 & 53.3 & 57.8 & $51.6 \mathrm{a}$ \\
\hline 120 & 38.5 & 58.8 & 49.3 & 63.0 & $52.4 \mathrm{a}$ \\
\hline Means & $41.4 \mathrm{~b}$ & $50.8 \mathrm{a}$ & $49.3 \mathrm{a}$ & $55.4 \mathrm{a}$ & \\
\hline
\end{tabular}

LSD value for FYM at 0.05 probability level= 5.50 .

LSD value for Phosphorus at 0.05 probability level $=5.09$.

Table 5 Represent the effect of FYM and phosphorus on thousand grain weight of wheat. Statistical analysis of data showed that effect of FYM and phosphorus significantly affected thousand grain weights. Mean values showed that maximum thousand grain weights (55.4 g) was found in the plot treated with 9 tons ha ${ }^{-1} \mathrm{FYM}$, while minimum ( $41.4 \mathrm{~g}$ ) was recorded from plot treated without FYM. However P at $120 \mathrm{~kg} \mathrm{ha}^{-1}$ produced maximum thousand grain weight (52.4 g) while minimum (45.3 g) was reported from plot treated with $0 \mathrm{~kg} \mathrm{P} \mathrm{ha}^{-1}$ While interaction between (P x FYM) were no significant.

\section{Harvest index (\%)}

Table 6: Harvest index $\left(\mathrm{kg} \mathrm{ha}^{-1}\right)$ of wheat as affected by FYM and Phosphorus.

\begin{tabular}{|c|c|c|c|c|c|}
\hline P (kg ha-1) & \multicolumn{5}{|c|}{ Farm yard Manure (tons ha-1) } \\
\hline & $\mathbf{0}$ & $\mathbf{3}$ & $\mathbf{6}$ & $\mathbf{9}$ & Means \\
\hline 0 & 37.6 & 43.8 & 44.6 & 47.5 & $43.4 \mathrm{a}$ \\
\hline 60 & 32.2 & 37.4 & 42.7 & 51.0 & $40.8 \mathrm{a}$ \\
\hline 90 & 35.0 & 45.6 & 44.5 & 47.4 & $43.1 \mathrm{ab}$ \\
\hline 120 & 39.2 & 37.1 & 38.8 & 44.4 & $39.9 \mathrm{~b}$ \\
\hline Means & $36.0 \mathrm{c}$ & $41.0 \mathrm{bc}$ & $42.6 \mathrm{ab}$ & $47.6 \mathrm{a}$ & \\
\hline
\end{tabular}

LSD value for FYM at 0.05 probability level $=4.85$.

LSD value for Phosphorus at 0.05 probability level $=2.86$. 
Data regarding harvest index is shown in (Table 6). Statistical analysis of data revealed that effect of FYM, phosphorus and interaction between the (P x FYM) significantly affected harvest index. Mean values showed that the maximum harvest index (47.6\%) was found in the plot treated with 9 tons ha ${ }^{-1} \mathrm{FYM}$, while minimum $(36.0 \%)$ was recorded from plot treated without FYM. However P at $0 \mathrm{~kg} \mathrm{ha}^{-1}$ produced maximum harvest index (43.4\%) while minimum (39.9\%) was reported from plot treated with $120 \mathrm{~kg} \mathrm{p} \mathrm{ha}^{-1}$. While interaction between (P x FYM) the maximum harvest index (51.0\%) was recorded from plot receiving 9 tons $\mathrm{ha}^{-1} \mathrm{FYM}$ and $60 \mathrm{~kg} \mathrm{p} \mathrm{ha}^{-1}$ while minimum (32.2\%) was recorded from plot without tons ha- ${ }^{-1}$ FYM and Phosphorus.

\section{Discussion}

The results showed that effect of FYM, phosphorus and interaction between the (PxFYM) significantly affected biological yield. Mean values showed that the maximum biological yield was found in the plot treated with FYM application at high rate, while minimum biological yield was recorded from plot treated without ton ha ${ }^{-1}$ FYM. Similarly phosphorus application at high rate produced maximum biological yield while minimum was 0 $\mathrm{kg} \mathrm{ha}^{-1}$ phosphorus. Similarly interaction showed the maximum biological yield. Our results are in line with Yousaf \& Ali [10].

The results showed that effect of FYM, phosphorus significantly affected grain per spike, while interaction between (P x FYM) was also found significant. Mean values showed that the maximum grain per spike was found in the plot treated with high level. While minimum was recorded from plot treated without ton $\mathrm{h}^{\mathrm{a}-1}$. However phosphorus at the rate of optimum rate produced maximum grain per spike while minimum was reported from plot treated without ton $\mathrm{ha}^{-1}$. Similarly interaction showed the maximum biological yield. Our results are in line with Antil [11].

The results showed that maximum spike length was recorded in plots treated phosphorus application at high rate. Low spike length value of was observed in plot that received no Phosphorus. Similarly FYM application at high rate gave maximum spike length value. The lowest value of spike length was observed in control plots that received no P and FYM. Increase in both FYM and $P$ shows increase in spike length. Our results are in line with Khan \& Hussain [12].

The results showed that effect of FYM, phosphorus significantly affected grain yield. Mean values showed that the maximum grain yield was found in the plot treated with high rate FYM, while minimum was recorded from plot treated with 0 FYM ton ha $^{-1}$. However phosphorus application at high rate produced maximum grain yield while minimum was reported from plot treated with $0 \mathrm{~kg} \mathrm{P} \mathrm{ha}^{-1}$. While interaction between (P $\mathrm{x}$ FYM) was found non-significant. Our results are in line with Alam et al. [13].

The results showed that effect of FYM and phosphorus significantly affected thousand grain weights. Mean values showed that maximum thousand grain weights was found in the plot treated with high rate FYM, while minimum was recorded from plot treated without FYM. However P application at high rate produced maximum thousand grain weight while minimum was reported from plot treated with $0 \mathrm{~kg} \mathrm{P} \mathrm{ha}^{-1}$ While interaction between $(\mathrm{P} \times \mathrm{FYM})$ were no significant. Our results are in line with Pervez et al. [14].

The results showed that effect of FYM, phosphorus and interaction between the (P x FYM) significantly affected harvest index [15-17]. Mean values showed that the maximum harvest index was found in the plot treated with high rate FYM, while minimum was recorded from plot treated without FYM. However $\mathrm{P}$ at $0 \mathrm{~kg} \mathrm{ha}^{-1}$ produced maximum harvest index while minimum was reported from plot treated with phosphorus application at high rate [18-22]. While interaction between (P x FYM) the maximum harvest index was recorded from plot receiving high rate FYM and optimum $\mathrm{Pha}^{-1}$ while minimum was recorded from plot without tons ha-1 FYM and Phosphorus. Our results are in line with Nazim et al. [24,25].

\section{Conclusion}

It was concluded from the results that application of $\mathrm{P}$ at the rate of $120 \mathrm{~kg} \mathrm{ha}^{-1}$ and FYM at the rate of 9 tons ha ${ }^{-1}$ improve the yield and yield components of wheat. It is recommended that $\mathrm{P}$ at the rate of $120 \mathrm{~kg} \mathrm{ha}^{-1}$ and FYM at the rate of 9 tons ha-1 should be used to improve the yield and yield components of wheat.

\section{References}

1. MINFAL (2009) Ministry of Food, Agriculture and livestock. Agriculture Statistics of Pakistan 2008-2009. Government of Pakistan, Islamabad, Pakistan.

2. Malik MA, M Irfan, ZI Ahmad, F Zahoor (2006) Residual effect of summer grain legumes on yield and yield components of wheat (Triticum aestivum L.). Pak J Agri Agril Engg Vet Sci 22: 9-11.

3. Mann RA, WA Jehangir, I Masih (2004) Improving crop and water productivity of rice-wheat system in Punjab, Pakistan. In: Proceedings of the $4^{\text {th }}$ International Crop Science Congress, Brisbane, Australia.

4. Idris M, MM Iqbal, SM Shah, W Muhammad (2001) Integrated use of organic and mineral nitrogen, and phosphorus on the yield, yield components, $\mathrm{N}$ and $\mathrm{P}$ uptake by wheat. Pak J Sci 20: 77-80.

5. Ahmad S, NE Jan, R Khan, Faridullah, N Din (2010) Wheat response to phosphorus under climatic conditions of Juglote, Pakistan. Sarhat J Agric 26(2): 229-233.

6. David C MH, Hajabbasi NA, Rezainejad (2003) Short and mid-tem effect of organic fertilizers on some physical properties. J Agri Nature Resour Sci Technol 6(4).

7. Greorich E, Drury CF, baldock JA, (2001) Changes in soil carbon under long term maize in monoculture and legume-based rotation. Can J Soil science 81(1): 21-31.

8. Griffin Chatha, A Hussain (2001) The amendment of organic manure enchances soil organic carbon more than the application of the same amount nutrient as inorganic fertilizer. J of Food Agri and Env 10 (2): 1371-1375.

9. Ahmad N, MT Saleem, IT Twyford (1992) Phosphorus research in Pakistan a review. In: Proc Symp on the role of phosphorus in crop production, NFDC, Islamabad, Pakistan, p. 59-92. 
10. Yousaf AAA, HK Ali (2010) Effects of FYM and cattle manure on wheat production and soil properties in the high terrace and karu soils in the river Nile state in the Sudan. Second RUFORUM biennial meeting Entebee, Uganda, Africa, pp. 153-156.

11. Antil RZ, M Sing (2007) Effects of organic manures and fertilizers on organic matter and nutrients status of the soil. Archives Agron. Soil Sci 53(5): 519-528.

12. Khan MA, I Hussain (2001) FYM effect on the potential yield of wheat on the potential yield of wheat in the light of Holy Quran. J Bio Sci 1(2): 62-64.

13. Alam SM, SA Shah, S Ali, MM Iqbal (2003) Wheat yield and P fertilizer efficiency as influenced by rate and integrated use of chemical and organic fertilizer 22(2): 72-76.

14. Pervez K, M Imtiaz, M Aslam SKH Shah, MY Memon, SH Siddiqui (2008) Effect of different nitoren and phosphorous ratio on the performance of wheat cultivar Khirman. Sarhad J Agric 24(2): 233-239.

15. Alasiri KO (2002) Effect of combine use of poultry manure and NPK on the seed yield of okra. Horticulture society of Nigeria Ibadan, Africa.

16. Ali H, N Tariq, S Ahmad, TH Chattha, A Hussain (2012) Effect of irrigation at different growth stages and phosphorus application methods on agronomic traits of wheat. J of Food Agri and Env 10(2): 1371-1375.

17. Alias A, M Usman, E Ullah, EA Warraich (2003) Effects of different phosphorus levels on the growth and yield of two cultivars of maize. Int J Agri Biol 5(4): 632-634.
18. Ghosh PK, Ramesh KK, Bandyopadhyay AK, Tripathi, KM Hati, et al. (2004) Comparative effectiveness of cattle manure, poultry manure. Phosphor compost and fertilizer- NPK on three cropping systems in vertical of semi-arid tropics. Bioresour Technol 95(1): 85-93.

19. Hashmi, Afzal R Ahmad (1984) Reported that under the ideal condition it could be possible to obtain the wheat yield of 20 tons ha ${ }^{-1}$. Soil Science 81: 34-65.

20. Haynes RJ, RS Swift (1991) Influence of mixed cropping rotation on organic matter content, water stable aggregation and cold porosity in a group of soil. Soil tillage Res 19: 77-87.

21. Hussain N, MB Khan, R Ahmad (2008) Influence of phosphorus application and sowing time on performance of wheat in calcareous soil. Int J Agri Biol 10: 399-404.

22. Masood T, R Gul, F Munsif, F Jalal, Z Hussain, et al. 2011. Effect of different phosphorus levels on the yield and yield components of maize. Sarhad J Agric 27(2): 167-170.

23. Memon MY, P Khan, M Imtiaz, JA Shah, N Depar (2011) Response of candidate wheat variety nia-8/7 to different levels/ratios of nitrogen and phosphorus. Pak J Bot 43(4): 1959-1963.

24. Nazim H, MB Khan, R Ahmad (2008) Influence of Phosphorous Application and Sowing time on performance of wheat in calcareous soils. Int J Agric Biol 10(4): 399-404.

25. Mortley DG, CB Smith, KT Demchak (1991) Fertilizer placement affects growth, fruit yield, and elemental concentrations and contents of tomato plants. J Amer Soc Hort Sci 116(4): 659-662.

\section{Your next submission with Juniper Publishers will reach you the below assets}

- Quality Editorial service

- Swift Peer Review

- Reprints availability

- E-prints Service

- Manuscript Podcast for convenient understanding

- Global attainment for your research

- Manuscript accessibility in different formats

( Pdf, E-pub, Full Text, Audio)

- Unceasing customer service

Track the below URL for one-step submission https://juniperpublishers.com/online-submission.php 